\title{
Obituaries
}

\section{STEPHEN DENIS HATT}

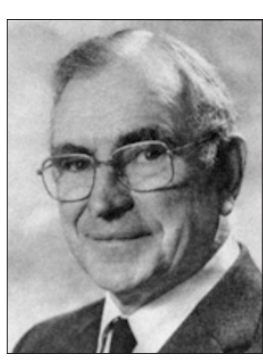

Stephen was

born in London

on the 30 July

1923. However, his family home was in Belgium in a village near Charleroi, where he attended the

local school until the age of 12. Stephen moved to a school in St Albans as a boarder in September 1936. In 1943 he volunteered for the RAF and was accepted for pilot training, undertaking this in Canada and gaining his wings there before returning to the Shetland islands to fly Catalinas as a member of 210 Squadron Coastal Command. Following demobilisation, he entered the dental school at St Andrews in October 1946, qualifying in 1950. After a brief spell in practice, he went to Dundee as a lecturer, moving to Manchester three years later where he completed his MDS in 1959. He moved to Sheffield in 1963 as consultant dental surgeon with a special interest in conservative dentistry. He was a great supporter of the Royal College of Surgeons of Edinburgh and in the period 1980-1983 was elected the last Convenor of Dental Fellows and then the first dean of the new Faculty of Dental Surgery. He was chair of the Association of Dental Hospitals from1975-1979. He was elected President of the British Society for Restorative Dentistry in 1984/5. He retired from his consultant post in 1988 at the age of 65 .

Stephen took a great interest in student affairs, umpiring staff-student cricket matches, and having a period as warden of Tapton Hall of Residence.
He was one of those individuals with great presence but who was always happy to offer thoughtful advice when requested. He retired to Norfolk but kept in regular touch with his many friends and former colleagues in Sheffield. He died on 10 March 2013 at the age of 89. To his widow Bobbi and his children Christopher, Deborah and Nigel, and their families, we extend our sympathy for their sad loss. His passing away will be felt by many former colleagues both in Sheffield and at the RCS Edinburgh, who will remember his skill as a clinician, administrator and as a reliable, professional friend.

Raymond Winstanley and Keith Figures

\section{JOYCE ISOBEL HEATH}

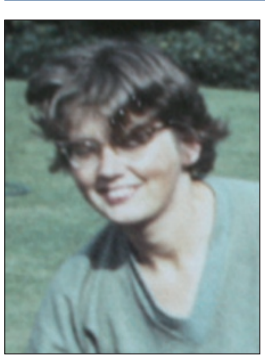

1926-2013

Joyce Isobel Heath (née Manning) died peacefully at her home in Bradford Peverell in Dorset on 7 August 2013. She was born in 1926 and lived as a child in East Horsley, Surrey. She was married to Colin A. J. Heath, who was also a dental surgeon. Joyce studied dentistry at the Royal, graduating with several awards in 1948. She often told us of the terror she felt doing her dissecting under the glass roof while the bombs were passing overhead! After graduating she worked as a house surgeon at both the Royal and Barts, where she was the first female on the staff as a resident. She worked briefly in London at a school clinic before helping her husband with their practice in the Epsom home. In 1966 the family moved to Chippenham in
Wiltshire where she worked as a dental officer. In 1977 she moved to Dorset and worked in a clinic at Dorchester before returning to Wiltshire and working with the forces at Tidworth. In addition to her dental skills she was a competent botanical and landscape artist, leaving a considerable portfolio, which was exhibited at her funeral. She was also a very knowledgeable gardener and took a great interest in alpine flowers, in the pursuit of which she travelled extensively. She leaves behind her daughter, Susan Herapath, and son, Mark Heath. She had two grandchildren.

Mark Heath 